\title{
The Malashan metamorphic complex in southern Tibet: Dominantly top- to-the north deformation and intrusive origin of its associated granites
}

\author{
Mutsuki Aoya†*, Simon R Wallis†, Tetsuo Kawakamił, J effrey Lee§ and Yu Wang ฯ \\ † Department of Earth and Planetary Sciences, Graduate School of Environmental Studies, Nagoya University, Nagoya, 464-8602, \\ JAPAN \\ ‡ Department of Earth Sciences, Faculty of Education, Okayama University, Okayama, 700-8530, JAPAN \\ $\$$ Department of Geological Sciences, Central Washington University, Ellensburg, WA 98926, USA \\ I Department of Geology, China University of Geosciences, Beijing, 100083, CHINA \\ *To whom correspondence should be addressed.E-mail:f030402r@mbox.nagoya-u.ac.jp
}

The kinematics of deformation associated with the formation of the south Tibetan metamorphic domes has important implication for the distribution of extensional (top-to-the north) tectonic regime represented by the STDS (South Tibetan Detachment System, Figure 1). However, this deformation has not been well-documented. Even for the Kangmar dome (Figure 1), the most accessible and well-documented metamorphic dome, two contrasting views exist about the kinematic nature of the associated deformation: (i) dominantly top-to-the north shear (Chen et al. 1990); and (ii) bulk pure shear reflected by a combination of top-to the north and top-to the south senses of shear in the northern and the southern parts of the dome, respectively (Lee et al. 2000). A second important point to be assessed is the origin of the granitic cores to the metamorphic domes. In the Kangmar dome the granite is thought to represent part of the basement root complex and not an intrusion during the Himalayan orogeny (Chen et al. 1990, Lee et al. 2000). To obtain new insights into these issues and to compare our new results with the Kangmar examples, structural and geochemical studies were carried in a metamorphosed region of Malashan area, located about $400 \mathrm{~km}$ west of the Kangmar dome (Figure 1)

\section{Granite bodies and associated metamorphism}

The Malashan area in southern Tibet is located within the socalled Tethyan Himalayan sequence on the north of the STDS (Figure 1). The area contains three two-mica granite bodies: Malashan, Cuobu and Paiku granites. Their surrounding lithologies are mainly calc-schists with minor amounts of peliticpsammitic schists. In the pelitic schists close to the granite bodies, garnet+staurolite+biotite assemblages are developed representing intermediate-pressure metamorphism similar to that seen in the Kangmar dome. In addition, pelitic schists from the area adjacent to the Cuobu and Paiku granites contain andalusite (Burg et al. 1984).

\section{Deformation phases and their distribution}

The dominant foliation developed in the schists surrounding the granite bodies is broadly horizontal and is defined as D2 foliation. An earlier deformation phase, D1, is defined by the foliation folded by D2 folds. The D2 stretching lineation, mainly defined by the alignment of pyrite fragments in calc-schists, is dominantly oriented N-S to NE-SW. In addition, D2 foliation is, on the whole, most strongly developed in the region adjacent to the granite bodies and becomes less strongly developed with increasing distance from the granite bodies. These features are strikingly similar to those of D2 recognized for the Kangmar dome (Chen et al. 1990, Lee et al. 2000).

\section{Kinematic indicators and shear senses}

The following kinematic indicators are used to determine the sense of shear for the D2 deformation: (i) asymmetry of quartzrich lenses in calc-schist; (ii) asymmetry of porphyroclasts such as pyrite in calc schist; (iii) vein sets representing shortening and stretching quarters of bulk strain; (iv) shear bands (S-C' fabric); and (v) opening direction of foliation boudinage that is oblique to stretching lineation. Especially the last indicator (oblique boudin neck) is widely applicable for the calc-schist of the Malashan area. The results show that with only few exceptions the sense of shear in the Malashan area is the top-to-the north.

\section{Origin of granite bodies}

The outer marginal zone of the Malashan granite is strongly affected by D2 deformation as in the case of the Kangmar dome. In contrast, the orientation distribution of biotite grains shows that the Cuobu granite is relatively less deformed. Other observations are: (i) the Cuobu granite has dykes originating from the main body and cross-cutting the surrounding D2 foliation; (ii) the Cuobu granite is associated with formation of andalusite and skarn in the adjacent metasediments; and (iii) the andalusite schist and skarn are moderately affected by the D2 deformation. These observations indicate that the Cuobu granite is an intrusive body that was emplaced during the later stages of the D2 deformation. On the other hand, geochemical studies for the Malashan and Cuobu granite show that these bodies have strikingly similar bulk chemical compositions suggesting that they are derived from the same type of original magma. Taking this into account the Malashan granite can also be interpreted as an intrusive body, but the much stronger D2 deformation suggests its emplacement was earlier.

\section{Implications}

The Malashan granite and its associated metamorphism and deformation show many similarities with the Kangmar dome. It is, therefore, possible to consider that the region around the Malashan granite forms a metamorphic dome similar to the Kangmar dome. However, the following conclusions of this study bear incompatibility with previous studies for the Kangmar dome: (i) The D2 deformation around the Malashan dome is associated with dominantly top-to-the north sense of shear; and (ii) the Malashan granite is interpreted as an intrusive body formed during the Himalayan orogeny. These results suggest that the formation mechanism of the south Tibetan metamorphic domes may need to be reevaluated. 


\section{References}

Burchfiel BC, Z Chen, KV Hodges, Y Liu, LH Royden, C Deng and J Xu. 1992. The south Tibetan detachment system, Himalayan orogen: Extension contemporaneous with and parallel to shortening in a collisional mountain belt. Geol Soc Am Special Paper 269: 1-41

Burg JP, M Guiraud, GM Chen and GC Li. 1984. Himalayan metamorphism and deformations in the North Himalayan Belt (southern Tibet, China). Earth and Planetary Science Letters 69: 391-400
Chen Z, Y Liu, KV Hodges, BC Burchfiel, LH Royden and C Deng. 1990. The Kangmar dome: A metamorphic core complex in southern Xizang (Tibet). Science 250: 1552-6

Lee J, BR Hacker, WS Dinklage, Y Wang, P Gans, A Calvert, JL Wan, W Chen, AE Blythe and W McClelland. 2000. Evolution of Kangmar Dome, southern Tibet: Structural, petrologic, and thermochronologic constraints. Tectonics 19: 872-95

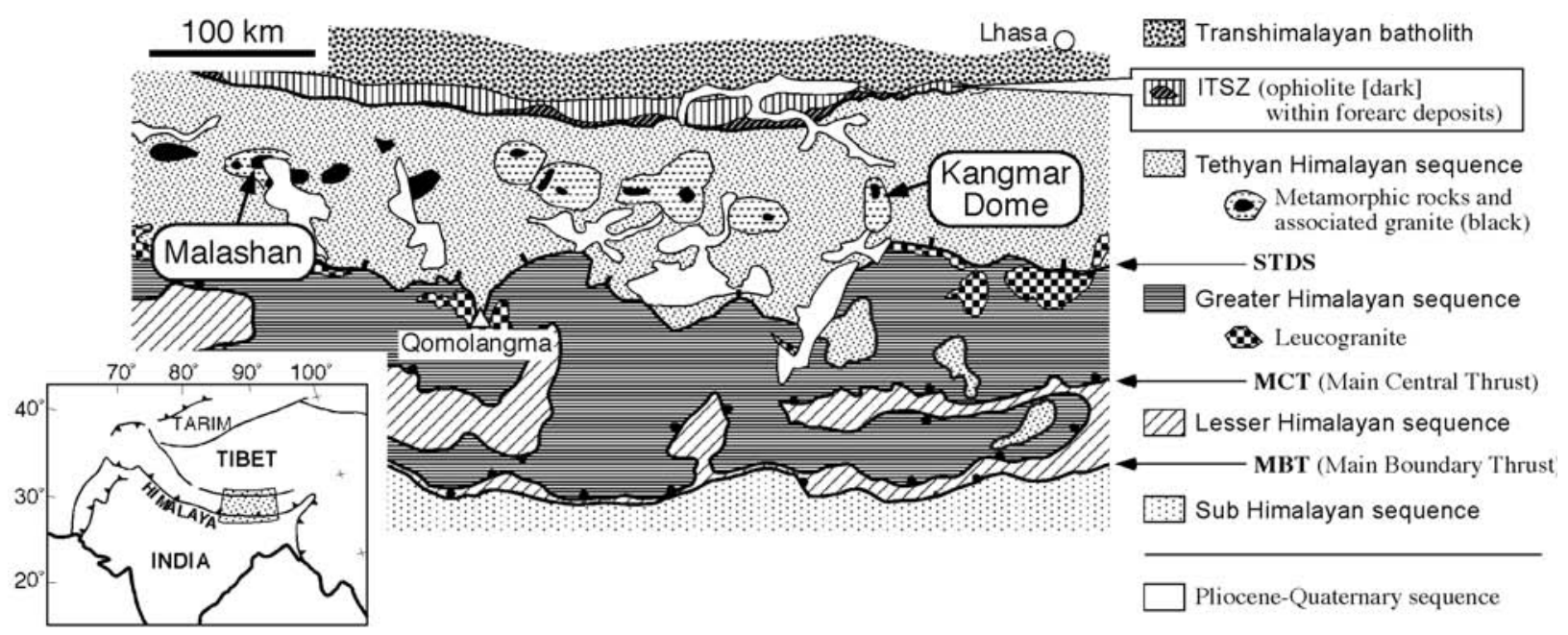

FIGURE 1. Tectonic map of southern Tibet with locality of the Malashan area (modified from Burchfiel et al. 1992) 